\title{
KONSERVASI SUMBERDAYA ALAM TAMBANG MARMER DALAM TINJAUAN PERSPEKTIF ISLAM (STUDI KASUS PT.INDUSTRI MARMER INDONESIA TULUNGAGUNG KECAMATAN BESUKI)'
}

\author{
Maya Zulfa Maslihatin \\ Program Studi S1 Ekonomi Islam-Fakultas Ekonomi dan Bisnis-Universitas Airlangga \\ E-mail : mayazulfamm@gmail.com \\ Moh. Qudsi Fauzy \\ Departemen Ekonomi Syariah-Fakultas Ekonomi dan Bisnis-Universitas Airlangga \\ E-mail : qudsifauzyl@gmail.com
}

\begin{abstract}
:
Conservation is a way of management which is done by men in using natural resources so that it can provide benefit and maintain the potentials to meet the needs and aspirations of the future generations. This research aims to find out the marble mine natural resources conservation in PT.Industri Marmer Indonesia Tulungagung within Islam's point of view. This research uses qualitative approach. Data collection is done by using interviews and direct observations towards the research object. Data checking is done by using triangulation by involving observations, interviews and documentions.

The results show that the economic conservation implementation of natural resources of marble mine in Islam's point of view has been implemented and done by PT. Industri Marmer Indonesia Tulungagung and also there are positive impacts towards the community in the form of factory waste management.
\end{abstract}

Keywords: Conservation, Marble Mine, PT. Industri Marmer Indonesia Tulungagung

\section{PENDAHULUAN}

Konservasi adalah suatu usaha pengelolaan yang dilakukan oleh manusia dalam memanfaatkan sumberdaya alam sehingga dapat menghasilkan keuntungan sebesarbesarnya secara berkelanjutan untuk generasi manusia saat ini, serta tetap memelihara potensinya untuk memenuhi kebutuhan-kebutuhan dan aspirasi generasi yang akan datang. Program konservasi diterapkan dengan tujuan agar para pelaku usaha pertambangan di wilayah Kabupaten Tulungagung dapat melakukan pengelolaan bahan galian hasil penambangan secara baik, benar, bijaksana, berdayaguna dan berhasil untuk memperoleh manfaat yang optimal dan berkesinambungan bagi masyarakat serta memberikan kontribusi bagi

perekonomian daerah. Tercatat beragam kegiatan eksplorasi yang berkaitan dengan usaha pertambangan bahan galian di wilayah Kabupaten Tulungagung, diantaranya telah mencapai peningkatan hingga tahap penambangan, pengolahan dan pemasaran. Dalam perjalanannya tidak semua usaha pertambangan tersebut berhasil dikembangkan hingga tahap penambangan atau ekploitasi, karena kuantitas dan kualitas sumber daya atau cadangan bahan galian yang diharapkan masih dalam proses pembuktian atau tidak memenuhi persyaratan kelayakan untuk ditambang berdasarkan pengkajian geologi, kelayakan dan ekonomi.

1) Jurnal ini merupakan bagian dari skripsi Maya Zulfa, NIM : 041211431007 , yang di uji pada 23 Mei 2016. 
Maslihatin, et al/Jurnal Ekonomi Syariah Teori dan Terapan Vol. 3 No. 11 November 2016: 915-927; KONSERVASI SUMBERDAYA ALAM TAMBANG MARMER DALAM TINJAUAN PERSPEKTIF ISLAM (STUDI KASUS PT.INDUSTRI MARMER INDONESIA TULUNGAGUNG KECAMATAN BESUKI)

Kerusakan lingkungan pada saat ini semakin bertambah parah. Kelalaian dan dominasi manusia terhadap alam dan pengelolaan lingkungan yang tidak beraturan membuat segala unsur harmoni dan sesuatu yang tumbuh alami berubah menjadi kacau dan sering berakhir menjadi bencana. Indonesia menggantungkan hidup dan perekonomiannya pada kesuburan sumber daya alam (SDA) yang melimpah misalnya, minyak bumi batu bara, tembaga,emas dan timah. Ketergantungan ini menguras isi perut bumi kemudian menyisakan lobanglobang raksasa, pencemaran udara dan air, serta sisa galian yang memerlukan biaya pengembalian alam (restorasi) pembabatan hutan alam terus terjadi. Bahaya yang diakibatkan menurutkan kehendak nafsu sangat jelas dampaknya pada kehancuran bumi. Hal ini dapat berupa eksploitasi yang berlebihan dan tidak mempertimbangkan daya dukung lingkungan, pemborosan, menguras sesuatu yang tidak penting dan tidak efisien. Konservasi sumberdaya alam dapat dijaga dan dilestarikan dalam jangka panjang namun. Terdapat dampak dari adanya pendirian perusahaan dampak tersebut menimbulkan dampak negatif, adapun dampak negatif pada PT IMIT pada proses pengangkutan material dan pengolahan marmer juga akan menimbulkan pencemaran lingkungan yang berpotensi mengancam pada kesehatan masyarakat. Dari sisi geologi eksplorasi tambang marmer juga berpotensi menimbulkan terjadinya tanah longsor. Selain dampak negatif, terdapat eksternalitas positif dari kegiatan PT IMIT dampak positif merupakan dampak dari suatu kegiatan yang dilakukan oleh suatu pihak terhadap orang lain tanpa adanya kompensasi dari pihak yang diuntungkan, adapun dampak positif yaitu Tulungagung merupakan salah satu sentra industi marmer nasional. Pada tahun 1980 - 1987 kebutuhan marmer di Indonesia sebagian besar dipenuhi oleh marmer impor dari Italia dan sebagian kecil dari dalam negeri yang dihasilkan dari daerah Tulungagung, Citatah, Lampung, dan Payakumbuh, Sumatra Barat. Namun pada tahun 1990 produk dalam negeri mampu mendominasi pemenuhan kebutuhan marmer di Indonesia. Hal tersebut tidak lepas dari peningkatan eksploitasi marmer sebagai salah satu industri yang menunjang pembangunan nasional. Jumlah industri kerajinan atau UKM marmer di kabupaten Tulungagung mencapai 201 unit penambangan.

\section{LANDASAN TEORI}

Suparmoko

(1997:22) mendefinisikan bahwa konservasi adalah suatu tindakan untuk mencegah pengurasan sumberdaya alam dengan cara pengambilan yang tidak berlebihan sehingga dalam jangka panjang sumberdaya alam tetap tersedia. Konservasi dapat juga diartikan menjaga kelestarian terhadap alam demi 
Maslihatin, et al/Jurnal Ekonomi Syariah Teori dan Terapan Vol. 3 No. 11 November 2016: 915-927; KONSERVASI SUMBERDAYA ALAM TAMBANG MARMER DALAM TINJAUAN PERSPEKTIF ISLAM (STUDI KASUS PT.INDUSTRI MARMER INDONESIA TULUNGAGUNG KECAMATAN BESUKI)

kelangsungan hidup manusia. Tindakantindakan konservasi dapat berupa beberapa cara antara lain :

1. Melakukan perencanaan terhadap pengambilan sumberdaya alam, yaitu dengan pengambilan secara terbatas, dan tindakan yang mengarah pada pengurasan perlu di cegah.

2. Mengusahakan eksploitasi sumberdaya alam secara efisien yakni dengan limbah sedikit mungkin.

3. Mengembangkan sumberdaya alternatif atau mencari sumberdaya pengganti sehingga sumberdaya alam yang terbatas jumlahnya dapat disubstitusikan dengan sumberdaya alam jenis yang lain.

4. Menggunakan unsur-unsur teknologi yang sesuai dalam mengeksploitasi sumberdaya alam agar dapat menghemat penggunaan sumberdaya tersebut dan tidak merusak lingkungan,

5. Mengurangi, membatasi dan mengatasi pencemaran lingkungan karena pencemaran lingkungan akan mengakibatkan cadangan sumberdaya alam semakin cepat habis karena kepunahan, seperti ikan, tanah, dan sebagainya.

Tindakan konservasi ini perlu dilakukan khusunya bagi sumberdaya alam yang sifatnya tidak dapat pulih dengan sendirinya. Tindakan konservasi bagi sumberdaya alam yang dapat pulih (renewable resources) dapat dilakukan dengan lebih hati-hati, misalnya untuk konservasi hutan dapat dilakukan dengan berbagai sistem tebang pilih, reboisasi dan penghijauan.

$$
\text { Menurut Suparmoko (1997:105) }
$$

Ada beberapa variabel ekonomi yang mempengaruhi konservasi sumberdaya alam yang akan dijelaskan sebagai berikut :

1. Tingkat bunga

2. Masalah ketidakpastian

3. Perpajakan

4. Pengaruh Kebijakan Harga

5. Hak Penguasaan

6. Persewaan

7. Bentuk Pasar

8. Ketidakstabilan Ekonomi

Menurut Mangunjaya

(2005:52) Konservasi alam dalam Islam, rnenjelaskan bahwa sampai hari ini konsep pelestarian alam (nature conservation) yang masih mencari bentuk sehingga perlu dicari alternasi, Islam mempunyai ketentuan mengenai perlindungan alam dan termasuk dalam syariat.

Di dalam Islam di kenal istilah Hima' yaitu suatu kawasan yang khusus dilindungi oleh pemerintah (Imam Negara atau khalifah) atas dasar syariat guna melestarikan hidupan liar serta hutan. Nabi pernah mencagarkan kawasan sekitar Madinah sebagai hima 'guna melindungi lembah, padang rumput dan tutnbuhan yang ada di dalamnya. Nabi melarang masyarakat mengolah tanah tersebut karena lahan itu untuk kemaslahatan umum dan kepentingan pelestariannya. 
Maslihatin, et al/Jurnal Ekonomi Syariah Teori dan Terapan Vol. 3 No. 11 November 2016: 915-927; KONSERVASI SUMBERDAYA ALAM TAMBANG MARMER DALAM TINJAUAN PERSPEKTIF ISLAM (STUDI KASUS PT.INDUSTRI MARMER INDONESIA TULUNGAGUNG KECAMATAN BESUKI)

Menurut Utami (2008:157) dari berbagai pelajaran yang ada, kegiatan konservasi yang pernah dicontohkan oleh Rasulullah SAW dan para sahabat serta ayat-ayat al-Quran sebagai acuan utama,adabeberapakonsepkonservasidal am Islam yaitu :

1. Menjaga Keseimbangan Jiwa

2. Menjaga Siklus Hidrologi (Air)

3. Menjaga Kestabilan Atmosfir (Udara)

4. Reboisasi

5. Menjaga Kawasan Khusus (Kawasan Penambangan).

\section{METODE PENELITIAN}

Penelitian ini menggunakan pendekatan kualitatif. Dimana data yang terkumpul akan diolah dianalisis secara deskriptif. Penelitian kualitatif merupakan penelitian yang menekankan pada proses yang tidak menjadikan hasil penelitian sebagai orientasi keberhasilan suatu data melainkan kebenaran dari hipotesis yang disajikan melalui hasil penelitian gejala sosial yang ada. Menurut Yin (2009:2) pendekatan kualitatif adalah pendekatan dengan menggunakan data yang berupa kalimat tertulis atau lisan, peristiwaperistiwa, pengetahuan atau proyek studi yang bersifat deskriptif.

\section{Jenis dan Sumber Data}

Data yang digunakan dalam penelitian kualitatif ini adalah data primer dan sekunder. Data primer adalah data dari hasil wawancara dan observasi langsung di lapangan. Sedangkan data sekunder berdasarkan studi literatur dan juga dokumen yang berkaitan dari arsip
PT.IMIT Tulungagung. Data primer di dapat melalui metode wawancara yang memungkinkan peneliti bertatap muka langsung dengan informan untuk menggali informasi dengan lebih mendalam sehingga mendapatkan hasil yang valid. Data primer dalam penelitian ini diperoleh dari wawancara mendalam (indepth interview).

\section{Teknik Pengumpulan Data}

Teknik pengumpulan data merupakan langkah yang paling strategis dalam penelitian, karena tujuan utama dari penelitian adalah mendapatkan data, sehingga peneliti tidak akan mendapatkan data yang memenuhi standart data yang ditetapkan (Sugiyono, 2010:225)

Dalam penelitian kualitatif, pengumpulan data dilakukan pada natural setting (kondisi yang alamiah), sumber data primer, dan teknik pengumpula data lebih banyak pada observasi berperan serta (participan observation), wawancara mendalam (in depth interview) dan dokumentasi. Secara umum terdapat empat macam teknik pengumpulan data yaitu observasi, wawancara, dokumentasi, dan gabungan atau triangulasi.

\section{Teknik Analisis}

Analisis data dalam penelitian kualitatif, dilakukan pada saat pengumpulan data berlangsung, dan setelah selesai pengumpulan data dalam periode tertentu (Sugiyono, 2010:246)

Pada saat wawancara, peneliti sudah melakukan analisis terhadap jawaban yang diwawancarai. Bila jawaban yang diwawancarai setetlah dianalisis terasa belum memuaskan, maka 
Maslihatin, et al/Jurnal Ekonomi Syariah Teori dan Terapan Vol. 3 No. 11 November 2016: 915-927; KONSERVASI SUMBERDAYA ALAM TAMBANG MARMER DALAM TINJAUAN PERSPEKTIF ISLAM (STUDI KASUS PT.INDUSTRI MARMER INDONESIA TULUNGAGUNG KECAMATAN BESUKI)

peneliti akan melanjutkan pertanyaan lagi, sampai tahap tertentu, diperoleh data yang dianggap kredibel. Aktivitas dalam analisis data kualitatif dilakukan secara interaktif dan berlangsung secara terus menerus sampai tuntas, sehingga datanya sudah jenuh. Aktivitas dalam analisis data, yaitu reduksi data, display data, dan kesimpulan.

\section{HASIL DAN PEMBAHASAN}

Penelitian ini mengacu pada petunjuk pelaksanaan teknik resmi/formal yang berkaitan dengan konservasi di bidang energi dan sumberdaya mineral berdasarkan Peraturan Perundangundangan yang diterbitkan oleh Departemen Energi dan Sumberdaya Mineral. Secara legal hukum acuan pelaksanaan evaluasi adalah Pedoman Pengawasan Konservasi Bahan GalianPertambangan Umum yang tercantum dalam Lampiran XI Keputusan Menteri Energi dan Sumberdaya Mineral Nomor :1453K/29/MEM/2000 Tanggal 3 November 2000 terkait dengan pengawasan konservasi bahan galian berlaku untuk setiap usaha pertambangan atas semua bahan galian golongan, kecuali bahan galian minyak dan gas bumi. Beberapa ahli menyatakan bahwa permasalahan muncul dikarenakan adanya kegiatan industri mengekspliotasi sumberdaya alam secara berlebihan. Eksploitasi tidak terkendali ini kemudian menimbulkan berbagai dampak lingkungan terutama terhadap manusia berupa penyakit bahkan kematian. Akibat peristiwa ini maka anjuran konservasi terhadap lingkungan dan sumberdaya alam terus mendesak harus dimunculkan sebagai arus utama kegiatan pembangunan.

Islam telah memunculkan perintah konservasi sejak turunnya Nabi Adam as hingga diikuti oleh para nabi kemudian sampai kepada Nabi Muhammad saw. Ada atau tidak permasalahan lingkungan, menurut Islam kegiatan konservasi adalah usaha yang harus dilakukan secara sungguh-sungguh, terus menerus tanpa henti. Marmer adalah salah satu lambang dari Kabupaten Tulungagung karena sebagian pemasukan daerah adalah dari penjualan marmer. Namun, marmer adalah sumberdaya alam yang tidak pulih atau tidak dapat diperbaharui.

Implementasi konservasi sumberdaya alam yang dilakukan oleh PT.Industri Marmer Indonesia Tulungagung diantaranya adalah sebagai berikut :

\section{Penambangan marmer}

Dalam bidang penambangan, PT.IMIT telah bekerjasama dengan ahli geologi dan melakukan penelitian terhadap kualitas marmer dan jangka waktu gunung marmer tersebut untuk dimanfaatkan. Para ahli geologi mengatakan bahwa gunung marmer milik PT. Industri Marmer Indonesia Tulungagung sejak tahun 1961 masih terpakai sekitar 35\% dari luas penambangan $12 \mathrm{Ha}$. Terdapat gunung marmer yang serupa di daerah Makassar dengan kualitas yang sama dan bentuk 
Maslihatin, et al/Jurnal Ekonomi Syariah Teori dan Terapan Vol. 3 No. 11 November 2016: 915-927; KONSERVASI SUMBERDAYA ALAM TAMBANG MARMER DALAM TINJAUAN PERSPEKTIF ISLAM (STUDI KASUS PT.INDUSTRI MARMER INDONESIA TULUNGAGUNG KECAMATAN BESUKI)

gunung yang sama namun yang membedakan dengan gunung marmer yang ada di Tulungagung adalah tipe atau macam-macam tipe marmer yang telah dikualifikasi. Gunung marmer yang berada di Makassar akan mudah habis, dikarenakan bentuk gunung yang menyerupai kerucut jadi membuat proses penambangan tidak dapat dilakukan dengan teknik berjenjang.

\section{Efisiensi energi}

Efesiensi energi pada PT.IMIT dengan menggunakan energi seminimal mungkin seperti misalnya penggunaan listrik yang dibatasi untuk melakukan penghematan energi. Pada proses pengolahan marmer PT.IMIT melakukan penghematan dengan cara melakukan kegiatan pengolahan pada siang hari sedangkan pada malam hari tidak ada kegiatan pengolahan jadi kegiatan pengolahan marmer berlangsung pada jam kerja 08.00-16.00 WIB sedangkan pada proses penambangan terdapat salah satu alat berat yang harus menyala 24 jam karena apabila dimatikan energi yang digunakan untuk menyalakan alat tersebut lebih banyak.

\section{Pengolahan Limbah}

Seperti telah dijelaskan sebelumnya bahwa pengolahan limbah pada PT. Industri Marmer Indonesia Tulungagung diserahkan langsung kepada masyarakat sekitar. Terdapat dua jenis limbah marmer yaitu limbah padat yang berupa sisa penambangan yang telah di kualifikasi antara kualitas yang bagus dengan kualitas buruk. Marmer dengan kualitas buruk akan diberikan kepada PPLI (Paguyuban Pengelola Limbah Industri) untuk diolah menjadi barang yang mempunyai nilai dan dapat dijual. Sedangkan limbah cair adalah sisa limbah dari proses pengolahan marmer terdapat seperti kolam yang berisi limbah cair berwarna putih. Biasanya limbah cair tersebut dimanfaatkan oleh masyarakat sekitar untuk dolosit atau sebagai pengganti semen karena harganya yang terjangkau maka masyarakat lebih memlilih dolosit sebagai pengganti semen.

\section{Konservasi air}

Konservasi air adalah pengelolaan sumber daya air yang pemanfaatannya dilakukan secara bijaksana untuk menjamin kesinambungan persediaannya dengan tetap memelihara dan meningkatkan kualitas keanekaragaman dan nilainya, bertujuan mengusahakan terwujudnya kelestarian sumber daya alam hayati serta keseimbangan ekosistemnya. Pengelolaan konservasi air dilakukan melalui upaya pemanfaatan kembali limbah 
Maslihatin, et al/Jurnal Ekonomi Syariah Teori dan Terapan Vol. 3 No. 11 November 2016: 915-927; KONSERVASI SUMBERDAYA ALAM TAMBANG MARMER DALAM TINJAUAN PERSPEKTIF ISLAM (STUDI KASUS PT.INDUSTRI MARMER INDONESIA TULUNGAGUNG KECAMATAN BESUKI)

cair sehingga tidak mencemari lingkungan dengan membuang limbah cair tanpa memanfaatkan. Dengan memanfaatkan limbah cair tersebut maka terjadi efisiensi penggunaan air dan mencegah terjadinya pencemaran lingkungan yang disebabkan oleh limbah cair dari marmer.

\section{Keanekaragaman hayati}

Perlindungan keanekaragaman hayati dilakukan melalui upaya reklamasi lahan pasca penambangan dan penghijauan dengan cara reklamasi lahan penghijauan. Saat ini, PT.IMIT belum melakukan reklamasi lahan dikarenakan pelaksanaan reklamasi dapat dilakukan pasca penambangan selesai yang diputuskan oleh Badan Lingkungan Hidup kepada PT.IMIT. Gunung marmer yang dieksplorasi oleh PT.IMIT masih mencapai $35 \%$ untuk menanggulangi terjadinya longsor PT.IMIT melakukan penghijauan dengan menanam pohon disekitar area penambangan marmer. Penghijauan tersebut berfungsi juga sebagai pencegahan polusi suara yang ditimbulkan dari proses penambangan.

\section{Dampak Pelaksanaan Konservasi \\ Sumberdaya Alam Tambang Marmer PT. Industri Marmer Indonesia Tulungagung}

Terdapat beberapa dampak dari pelaksanaan konservasi sumberdaya alam tambang marmer PT. Industri Marmer Indonesia Tulungagung. Menurut key informan bapak sumarli mengatakan bahwa ada 3 dampak yang mempengaruhi konservasi dan proses penambangan.

Dampak dan hambatan tersebut diantaranya adalah sebagai berikut :

\section{Dampak Lingkungan}

Dampak lingkungan yang terjadi di sekitar PT.Industri Marmer Indonesia Tulungagung seperti polusi suara, polusi udara. Namun, polusi tersebut masih dalam kondisi aman karena tidak sampai menganggu kegiatan sehari-hari warga sekitar PT.IMIT. Terjadinya polusi suara dikarenakan bunyi alat-alat besar dalam proses penambangan marmer yang terdengar hingga pemukiman warga. Pihak PT.IMIT sendiri telah mengantisipasi dengan menanam pepohonan disekitar area penambangan agar meminimalisir terjadinya polusi suara yang dapat menganggu pemukiman warga yang berjarak sekitar $300 \mathrm{~m}$ dari area penambangan.

Sementara polusi udara terjadi karena adanya truk pengangkut limbah marmer yang berlalu lalang keluar-masuk pabrik sehingga membuat pemukiman warga sedikit terkena debu akibat adanya aktivitas dari PT.IMIT. Namun, warga sekitar pabrik tidak merasa terganggu akan hal tersebut mereka menganggap hal tersebut sudah biasa. Saat peneliti mewawancarai salah satu 
Maslihatin, et al/Jurnal Ekonomi Syariah Teori dan Terapan Vol. 3 No. 11 November 2016: 915-927; KONSERVASI SUMBERDAYA ALAM TAMBANG MARMER DALAM TINJAUAN PERSPEKTIF ISLAM (STUDI KASUS PT.INDUSTRI MARMER INDONESIA TULUNGAGUNG KECAMATAN BESUKI)

warga yaitu bapak Supani mengatakan bahwa warga sekitar pabrik telah terbiasa dengan aktivitas yang dilakukan PT.IMIT dan tidak merasa terganggu. Pak Agus menambahkan bahwa dengan adanya konservasi sumberdaya alam diharapkan dapat meminimalisir adanya polusi yang dapat menganggu pemukiman warga sekitar PT.IMIT karena konservasi menggunakan sumberdaya dengan bijaksana.

\section{Dampak ekonomi}

Terdapat beberapa dampak ekonomi yang dapat mempengaruhi konservasi sumberdaya alam tambang marmer di PT.Industri Marmer Indonesia Tulungagung. Yang pertama adalah kenaikan dollar, Pak Sumarli mengatakan bahwa terdapat alat yang harus impor dari Italia jadi apabila terjadi kenaikan dollar akan berpengaruh pada konservasi. Apabila terjadi kenaikan harga maka akan lebih baik melakukan konservasi. Suatu perubahan harga yang merata pengaruhnya sepanjang periode perencanaan tidak akan memberikan dorongan untuk mengubah distribusi waktu tingkat penggunaan sumberdaya alam.

Yang kedua adalah ketidakstabilan ekonomi, ketidakstabilan ekonomi selalu dihadapi oleh perusahaan karena memang merupakan bagian dari proses produksi. Ketidakstabilan akan meningkatkan pelvang ketidakpastian dalam proses produksi sehingga akan mempengaruhi keputusan konservasi.
Namun pihak PT.IMIT sendiri tetap melakukan penambangan sebagaimana biasanya agar tidak mempengaruhi proses pemasaran. Proses penambangan pada PT.IMIT telah ditentukan dan dilaksanakan dengan baik agar tidak terjadi deplisi.

\section{Hambatan Konservasi}

Terjadi hambatan dalam melakukan konservasi yang terjadi di PT.IMIT adalah seperti hambatan cuaca yang tidak menentu membuat proses penambangan menjadi terhambat karena truk tidak dapat melewati jalur penambangan. Hambatan yang kedua adalah hambatan teknologi dimana pihak PT.IMIT belum melakukan perbaikan teknologi dan masih menggunakan alat yang manual. Hal tersebut yang menghambat proses penambangan sehingga dapat memakan waktu yang lama.

\section{Implementasi Konservasi dari Segi Menjaga Keseimbangan Jiwa}

Menjaga keseimbangan jiwa adalah hubungan antara Alloh swt, manusia dan alam. Ketiganya sangat berhubungan erat dalam mengambil manfaat dalam sumberdaya alam. Bapak Andi mengatakan bahwa manusia diberi akal dan pikiran agar manusia dapat berpikir secara rasional untuk mengambil sumberdaya alam yang telah diciptakan oleh Alloh swt. Manusia biasanya tidak cukup puas sehingga akan mengambil secara terus menerus dan dapat mengakibatkan sumberdaya tersebut 
Maslihatin, et al/Jurnal Ekonomi Syariah Teori dan Terapan Vol. 3 No. 11 November 2016: 915-927; KONSERVASI SUMBERDAYA ALAM TAMBANG MARMER DALAM TINJAUAN PERSPEKTIF ISLAM (STUDI KASUS PT.INDUSTRI MARMER INDONESIA TULUNGAGUNG KECAMATAN BESUKI)

akan cepat habis. Seperti dituliskan dalam surat Al-An'am: 141

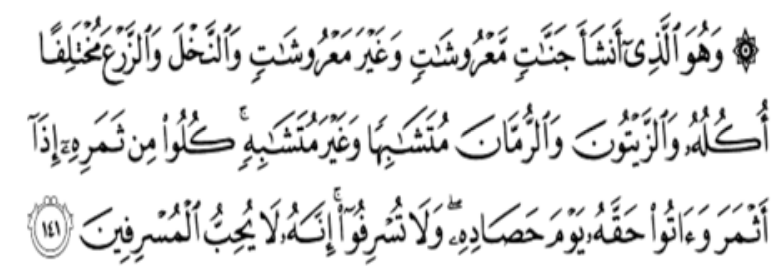

wahuwa alladzii ansya-a jannaatin ma'ruusyaatin ma'ruusyaatin waghayra walnnakhla waalzzar'a mukhtalifan ukuluhu waalzzaytuuna waalrrummaana mutasyaabihan waghayra mutasyaabihin kuluu min tsamarihi idzaa atsmara waaatuv haqqahu yawma hashaadihi walaa tusrifuu innahu laa yuhibbu almusrifiina

Artinya : dan Dialah yang menjadikan kebun-kebun yang berjunjung dan yang tidak berjunjung, pohon korma, tanam-tanaman yang bermacammacam buahnya, zaitun dan delima yang serupa (bentuk dan warnanya) dan tidak sama (rasanya). makanlah dari buahnya (yang bermacammacam itu) bila Dia berbuah, dan tunaikanlah haknya di hari memetik hasilnya (dengan disedekahkan kepada fakir miskin); dan janganlah kamu berlebih-lebihan. Sesungguhnya Allah tidak menyukai orang yang berlebih-lebihan.

Ayat tersebut menjelaskan bahwa kita sebagai manusia harus memanfaatkan alam dengan baik dan benar serta tidak mengambil sumberdaya secara berlebih-lebihan karena Alloh swt tidak menyukai hal yang berlebih-lebihan. Setelah Allah ciptakan dengan baik dan dipersiapkan untuk dapat dimanfaatkan oleh orang-orang yang memakmurkannya. Allah tidak menyukai pada perusakan bumi dan pelakunya, baik perusakan itu berupa pengotoran, ketidakadilan ataupun penyalahgunaan lingkungan dari tujuan penciptaannya oleh Allah.

\section{Implementasi Konservasi dari Segi Menjaga Siklus Hidrologi (Air)}

Air merupakan komponen penyusun bumi yang terbesar. Sekitar $70 \%$ permukaan bumi terdiri dari air. Dari jumlah air sebanyak itu, hanya $3 \%$ saja yang merupakan air yang dapat dijadikan untuk minum dan berprduksi. Air disiklus (diputar) dengan kehendak Alloh agar keberadannya dapat terjaga secara terus menerus. Dengan adanya konservasi air adalah pengelolaan sumber daya air yang pemanfaatannya dilakukan secara bijaksana untuk menjamin kesinambungan persediaannya dengan tetap memelihara dan meningkatkan kualitas keanekaragaman dan nilainya, bertujuan mengusahakan terwujudnya kelestarian sumber daya alam hayati serta keseimbangan ekosistemnya. Islam memiliki sistem keyakinan yang cukup jelas bahwa Allah swt telah menjadikan sumber daya alam dan lingkungan daya dukung bagi kehidupan. Fakta spiritual menunjukkan bahwa Allah swt telah memberikan fasilitas daya dukung lingkungan bagi kehidupan manusia. Pihak PT.IMIT telah mengelola air dengan baik sehingga dapat dipastikan tidak mencemari sumur-sumur di pemukiman warga sekitar meskipun adanya limbah cair.

Implementasi Konservasi dari Segi Menjaga Kestabilan Atmosfir (Udara) 
Maslihatin, et al/Jurnal Ekonomi Syariah Teori dan Terapan Vol. 3 No. 11 November 2016: 915-927; KONSERVASI SUMBERDAYA ALAM TAMBANG MARMER DALAM TINJAUAN PERSPEKTIF ISLAM (STUDI KASUS PT.INDUSTRI MARMER INDONESIA TULUNGAGUNG KECAMATAN BESUKI)

Kestabilan atmosfir dalam mengelola lingkungan sangat dibutuhkan. Karena pencemaran udara berhubugan langsung dengan kesehatan lingkungan sekitar. Sebagai manusia, kita harus menjaga dan memelihara lingkungan dengan baik dan tidak boleh merusaknya. Di PT.Industri Marmer Indonesia Tulungagung terdapat pencemaran udara seperti adanya truk yang lalu-lalang membawa limbah marmer untuk didistribusikan kepada warga sekitar. Pak Sumarli mengatakan bahwa warga tidak merasa terganggu akan adanya aktivitas perusahaan tersebut.

Alloh telah berfirman dalam QS. Al 'araf : 56

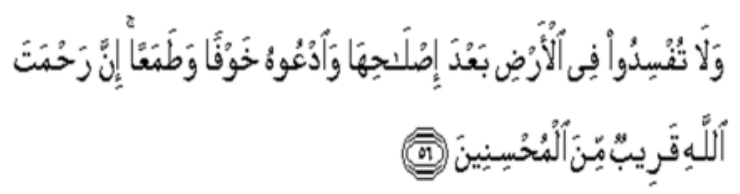

Walaatufsiduu filardhiba'da ishlaahihaa wad'uuhukhaufan wathama'an innarahmatallahi qariibun minal muhsiniin.

Artinya: dan janganlah kamu membuat kerusakan di muka bumi, sesudah (Allah) memperbaikinya dan Berdoalah kepada-Nya dengan rasa takut (tidak akan diterima) dan harapan (akan dikabulkan). Sesungguhnya rahmat Allah Amat dekat kepada orang-orang yang berbuat baik.

Ayat tersebut menjelaskan bahwa kita sebagai manusia tidak boleh melakukan kerusakan di muka bumi ini, karena alam adalah anugerah dari Alloh swt jadi kita harus menjaganya dengan baik. Seperti halnya kita tidak boleh membuat pencemaran atau polusi udara semua dapat ditanggulangi dengan cara yang baik. Hubungan antara manusia dengan alam sangat erat karena keduanya sama-sama diciptakan oleh Alloh swt. Jadi manusia sebagai makhluk Alloh swt yang diberi akal harus menjaga lingkungan dengan baik tanpa harus merusak lingkungan tersebut. Begitu juga sumberdaya alam yang harus dikelola dengan baik tidak berlebih-lebihan dalam mengambilnya selain itu apabila berlebihlebihan dalam memanfaatkan sumberdaya dapat terjadi bencana alam. Masalah polusi udara tidak dapat dihilangkan namun dapat diminimalisir dengan melakukan penghijauan disekitar pabrik PT.IMIT.

\subsubsection{Implementasi Konservasi dari Segi Reboisasi}

Penanaman pohon di suatu kawasan atau lahan, akan memberi manfaat lebih besar terhadap alam, seperti menyediakan makanan bagi manusia dan hewan, membersihkan dan menyejukkan udara disekitarnya.

Penghijauan atau reboisasi merupakan amalan sholeh yang mengandung banyak manfaat bagi manusia di dunia dan untuk membantu kemashlahatan akhirat manusia. Tanaman dan pohon yang ditanam oleh seorang muslim memiliki banyak manfaat seperti pohon itu dapat menjadi naungan bagi manusia dan hewan yang lewat, buah dan daunnya terkadang bisa dimakan, batangnya bisa dibuat menjadi berbagai macam peralatan, akarnya bisa mencegah terjadinya erosi dan banjir, 
Maslihatin, et al/Jurnal Ekonomi Syariah Teori dan Terapan Vol. 3 No. 11 November 2016: 915-927; KONSERVASI SUMBERDAYA ALAM TAMBANG MARMER DALAM TINJAUAN PERSPEKTIF ISLAM (STUDI KASUS PT.INDUSTRI MARMER INDONESIA TULUNGAGUNG KECAMATAN BESUKI)

daunnya bisa menyejukkan pandangan bagi orang yang melihatnya, dan pohon juga bisa menjadi pelindung dari gangguan tiupan angin, membantu sanitasi lingkungan dalam mengurangi polusi udara, dan masih banyak lagi manfaat tanaman dan pohon.

Reboisasi di sekitar pemukiman warga sekitar PT.Industri Marmer Indonesia Tulungagung dirasa kurangnya kesadaran oleh warga sekitar. Namun, pihak PT.IMIT sendiri telah menanam pohon disekitar pabrik sebagai penyejuk. Sedangkan dia area penambangan juga ditanam pohon-pohon agar mengurangi polusi suara yang dapat menganggu pemukiman warga. Polusi suara yang diakibatkan oleh proses penambangan marmer dengan menggunakan alat berat dan membuat bising.

\section{Implementasi Konservasi dari Segi \\ Menjaga Kawasan Khusus (Kawasan Penambangan Marmer)}

Kawasan khusus atau kawasan penambangan marmer adalah kawasan yang memiliki peran untuk menjaga keseimbangan alam baik ekologi, ekonomi maupun sosial. Kawasan ini ditetapkan berdasarkan aturan baik pemerintah maupun kesepakatan bersama dalam masyarakat.

Dalam Islam ketentuan mengenai perlindungan alam termasuk dalam syariat. Dalam Islam terdapat Hima' yaitu kawasan khusus dilindungi oleh pemerintah atas dasar syariah guna melestarikan lingkungan atau sumberdaya alam. Hal tersebut bertujuan agar sumberdaya alam tidak disalahgunakan oleh pihak-pihak yang tidak bertanggungjawab. Seperti penambangan liar yang marak dilakukan oleh warga sekitar hanya untuk kepentingan sepihak saja. Untuk menghindari hal tersebut, perlu adanya peran pemerintah dalam pengawasan kawasan pertambangan marmer di Tulungagung.

Pemerintah

kabupaten

Tulungagung setiap tahunnya melakukan kunjungan ke PT.IMIT dan pabrik-pabrik lain selain PT.IMIT untuk melakukan pemeriksaan terkait izin penambangan. Banyak warga yang tidak bertanggungjawab dan melakukan penambangan liar tanpa seizin dari pemerintah daerah.

\section{Rangkuman Pembahasan Konservasi}

Sumberdaya Alam dalam Perspektif Islam Para Informan Berdasarkan Konsep

\section{Konservasi Sumberdaya Alam dalam}

Islam Utami (2008:157)

1. Memiliki kesadaran akan pentingnya menjaga keseimbangan jiwa antara agama dan alam semesta. Senanstiasa menjaga dan melestarikan sumberdaya alam dengan sebaik-baiknya dan memanfaatkan dengan baik tanpa harus berlebih-lebihan dalam mengambil sumberdaya alam tersebut. Dari kelima informan semua memiliki kesadaran akan menjaga 
Maslihatin, et al/Jurnal Ekonomi Syariah Teori dan Terapan Vol. 3 No. 11 November 2016: 915-927; KONSERVASI SUMBERDAYA ALAM TAMBANG MARMER DALAM TINJAUAN PERSPEKTIF ISLAM (STUDI KASUS PT.INDUSTRI MARMER INDONESIA TULUNGAGUNG KECAMATAN BESUKI)

keseimbangan jiwa antara agama dengan alam semesta.

2. Menjaga keseimbangan siklus air, para informan ikut serta dalam menjaga keseimbangan siklus air mengelola limbah cair dengan baik memanfaatkan agar menjadi berguna dan dapat dijual kembali. Limbah cair yang dulunya dibuang begitu saja kini dapat dimafaatkan oleh warga sekitar dengan baik tanpa harus mencemari lingkungan sekitar.

3. Menjaga kestabilan atmosfir (udara), dalam menjaga kestabilan udara agar terhindar dari polusi udara maka dibutuhkan kesadaran dari berbagai pihak. Dari PT.IMIT sendiri telah melakukan penanaman pohon atau reboisasi agar mengurangi pencemaran udara. Polusi udara tidak dapat dihilangkan karena banyaknya truk yang keluar masuk pabrik namun dapat diminimalisir dengan cara penanaman pohon.

4. Reboisasi sangat penting untuk dilakukan untuk mengurangi polusi udara, namun informan 4 dan 5 dinilai kurang melakukan reboisasi atau penanaman pohon. Mereka mengaku karena kurangnya lahan hijau yang dapat ditanami pohon. Namun, dari pihak PT.IMIT sendiri telah melakukan penanaman pohon disekitar area pabrik untuk menghindari polusi udara dan polusi suara yang diakibatkan oleh aktivitas yang dilakukan oleh PT.Industri Marmer Indonesia Tulungagung.

5. Menjaga kawasan khusus atau area penambangan marmer, dilakukan atas dasar kelestarian lingkungan dibutuhkan peran pemerintah dalam hal ini. Dari kelima informan menyadari bahwa suatu saat gunung marmer yang diambil secara terus menerus maka akan habis karena marmer adalah sumberdaya alam yang tak pulih jadi harus dimanfaatkan dengan baik dan tidak boleh diambil secara berlebih-lebihan agar bisa dipakai untuk generasi yang akan datang.

\section{SIMPULAN}

Berdasarkan hasil penelitian mengenai "Konservasi Sumberdaya Alam dalam Persektif Islam" peneliti menyimpulkan bahwa:

Terdapat indikator-indikator yang mempengaruhi konservasi sumberdaya alam dalam perspektif Islam, yaitu :

a) Menjaga Keseimbangan Jiwa

b) Menjaga Siklus Hidrologi (Air)

c) Menjaga Kestabilan Atmosfir (Udara)

d) Reboisasi

e) Menjaga Kawasan

Khusus(Kawasan Penambangan Marmer)

PT.Industri Marmer Indonesia Tulungagung telah menerapkan dengan baik serta dukungan dari masyarakat sekitar pabrik 
Maslihatin, et al/Jurnal Ekonomi Syariah Teori dan Terapan Vol. 3 No. 11 November 2016: 915-927; KONSERVASI SUMBERDAYA ALAM TAMBANG MARMER DALAM TINJAUAN PERSPEKTIF ISLAM (STUDI KASUS PT.INDUSTRI MARMER INDONESIA TULUNGAGUNG KECAMATAN BESUKI)

sangat berperan dalam menjaga dan mengelola lingkungan konservasi.

Proses penambangan marmer dan pengolahan marmer telah dilakukan dengan baik oleh PT.Industri Marmer Indonesia Tulungagung dengan melibatkan 200 pekerja dan mempunyai pengaruh besar terhadap perekonomian daerah Tulungagung khususnya pada kecamatan Besuki. Hubungan antara masyarakat dan PT. Industri Marmer Indonesia Tulungagung terjalin sangat erat, terbukti dengan adanya masyarakat yang mampu mengolah limbah dari perusahaan. Limbah diolah dengan baik sehingga dapat menjadi mata pencaharian warga sekitar area PT.Industri Marmer Indonesia Tulungagung.

\section{DAFTAR PUSTAKA}

Cooper, Richard N. 1999. Kebijakan Lingkungan dan Sumber Daya Bagi Ekonomi Dunia. Bandung. PT. Remaja Rosdakarya.

Departemen Agama Republik Indonesia, Al-Qur'an dan terjemahnya, 2013

Fauzi, Akhmad. 2006. Ekonomi Sumber Daya Alam dan Lingkungan : Teori dan aplikasi. Jakarta : PT. Gramedia Pustaka Utama

Kusumawardani, Deni., Mintaroem, Karjadi., hidayati,Nuraini \& Parjatno, Sentot E.2008. Ekonomi Sumber Daya Alam \& Lingkungan. Surabaya: FEUA Mangunjaya, Fahruddin.2005. Konservasi Alam dalam Islam.Jakarta.Yayasan Obor Indonesia
Pedoman Pengawasan Konservasi Bahan

Galian Pertambangan Umum

Keputusan Menteri Energi Dan Sumber

Daya Mineral Nomor : 1453

K/29/Mem/2000 Tanggal : 3 November 2000

Sugiyono. 2010. Memahami Penelitian Kualitatif.Bandung: ALFABETA

Suparmoko. 1997. Penilaian ekonomi : Sumber Daya Alam dan Lingkungan edisi pertama. Yogyakarta : BPFE

Utami, Ulfah.2008.Konservasi Sumber Daya Alam Perspektif Islam dan Sains. Malang. UIN-Malang Press

Yin, Robert, K. 1981. Case Study Research Design and Methods. Penerjemah Mudzakir.2003. Jakarta: PT. Raja Grafindo Persada.

Yin, Robert, K. 2009. Case Study Research Design and Methods. United States of America: SAGE Asia-Pasific Ltd. 